\title{
Impression Management in Social Networking Sites and Its Motivation
}

\author{
Xinyu Liang ${ }^{1}$ \\ ${ }^{1}$ School of Architecture, Harbin Institute of Technology, Harbin 150006, Heilongjiang, China \\ *Corresponding author. Email: $1911478961 @ q q . c o m$
}

\begin{abstract}
Nowadays, social networking sites (SNS) have gradually become an important field for interpersonal interaction and communication. Due to the uniqueness of social networks, users' online interaction and offline face-to-face communication in social networks are different, but there is a certain correlation between them. Through analyzing the research on impression management and social networks by scholars at home and abroad, it is found that the impression management behavior of users in social network platforms is produced by the combined action of internal self-esteem needs motivation and external network environment factors motivation, which is conducive to have a further research on psychological research of certain behaviors generated by users in social network services.
\end{abstract}

Keywords: motivation for impression management, social network, self-expression, belonging, self-esteem

\section{INTRODUCTION}

Nowadays, in the rapidly developing Internet information age, interpersonal communication has gradually changed from "offline" face-to-face oral communication to "online" where only one expression package can represent one's point of view, while such online communication can also avoid unnecessary embarrassment. Therefore, impression management has become a common phenomenon in social communication. When users communicate and interact with each other, they will use different ways to establish the relationship between two people or achieve a certain purpose. Through the user's individual behavior, other users can form a certain expected impression of the user, thus changing the original impression of other users [1]. According to the 44th Statistical Reports on Internet Development in China, as of the first half of 2019, China's Internet users' average online time is 27.9 hours, which is 0.3 hours more than that of 2018. Among all kinds of APP (Application, Mobile Internet Application) used by mobile phone users, the proportion of APP using instant messaging reached $14.5 \%$, which is the longest duration.Among instant messaging APPs, WeChat is the most frequently used social network service platform in China in recent years, and users have the highest monthly activity. At the same time, it opens up a brand-new platform for people to conduct impression management in virtual social networks.

\section{LITERATURE REVIEW}

\subsection{Impression Management Research}

Impression management first appeared in the book The presentation of self in everyday life published by American sociologist Goffman [2], and he also became a pioneer in the research field of impression management. Goffman think impression management is a deceptive act. If life is a stage, people are actors on the stage, and anyone's social interaction can be regarded as a "dramatic performance". Everyone is actor, and "always try to make his performance close to the role he wants to present to the audience". The actor's various behaviors are regarded as a kind of self-realization, thus shaping the self-social image and identity in the eyes of others, which has laid a theoretical foundation for later scholars' research.

The 1960s and 1970s were the development stages of impression management theory. Until the late 1980s, scholars made more in-depth research on impression management and put forward more different theories on the definition of impression management. Schlenker and Arkin define impression management from the perspective of situation. Schlenker [3] believes that impression management is an act that affects the image of individuals in virtual situations or social interactions in real life. Arkin [4] puts forward the view that impression management is a means of self-display formed by users in order to achieve a certain impression or purpose in communication and interaction, but at the same time it also shows individual defects. Leary [5] and Kowanlski summarized the concept of impression management put forward by previous scholars, and defined impression management as the behavioral process of trying to control other individuals to form an impression on the controller. And Schlenker [6] 
an expression to represent what they express when socializing through WeChat, thus avoiding the impression formed by complicated language actions that is different from what users want to present. Li Weihua pointed out that the images presented by users on social networks are often similar to those in real life, presenting mostly positive ideal images [9]. However, Wu Xinyun believes that in social network interaction, different individuals perform in different ways to change or maintain other users' impression of themselves [10]

cybernetics, he proposed that impression management also includes people trying to actively control others' impression of them.

\subsection{Social Network}

Social Network Service(SNS), is a service generated on the basis of the network [6]. Boyd and Ellison [7] believe that users can display public or semi-public individual images on the social network platform, and interact and communicate with specific groups on the social network, at the same time to expand users' interpersonal relationships. China Internet Information Center defines the social network platform as an online application platform that helps users build interpersonal networks in social networks, which provides each user with a platform for self-display, communication and interpersonal relationships. Nowadays, social network has become a basic application in the Internet, and has attracted the attention of researchers in communication, psychology, management and other disciplines [6].

\subsection{Research on Impression Management in Social Networks}

WeChat, a social network platform, plays an obvious role in maintaining interpersonal relationships. It not only helps to construct interpersonal relationships between acquaintances and strangers, but also enables communication and interaction in such relationships. When people interact and communicate, whether they are engaging in face-to-face social interaction in reality or virtual social interaction on social network platforms, they will present their desired self-image and try to influence other people's views and opinions on their self-image. Such behavior is impression management in social networks.

Early research results show that the "offline" impression management theory is also applicable to the "online" virtual social network environment, and the environment of daily life is related to the community formed by social networks [8]. In social networks, users can show their image and show their taste by publishing articles and forwarding links among friends. If users present a perfect image in the social network, find like-minded friends and form a community, they will improve the efficiency of social interaction through the network platform. Individuals can manage their social behaviors by sending

\subsection{Motivation for Impression Management in Social Networks}

In 1990, American psychology professors Leary and Kowalski put forward Two-Component Mode of impression management. They pointed out that the behavior of impression management should be divided into two parts: Impression motivation and Impression construction [11].

There are reasons for people's behaviors, which can cause people to engage in certain activities and produce certain behaviors to satisfy people's wishes or thoughts. This is called motivation. Motivation is produced by the joint action of internal needs and external environmental factors. Impression motivation refers to the degree of personal will to control or influence the impression of oneself in others' hearts. Before we want to create a good impression in others' minds, we must have the motivation to start this behavior process. This motivation is the impression motivation [12].

According to the research of scholars in the following table, the motivations of impression management behavior in social networks are summarized as follows:

Table 1 Research on Motivation of Impression Management by Foreign Scholars

\begin{tabular}{|c|c|}
\hline Research Scholar & Motivation structure \\
\hline Rosenberg (1979) & $\begin{array}{c}\text { Get material rewards, enhance } \\
\text { self-esteem, and gain identity } \\
\text { recognition. }\end{array}$ \\
\hline $\begin{array}{c}\text { Baumeister(1982) } \\
{[13]}\end{array}$ & $\begin{array}{c}\text { Pleasing Audience and } \\
\text { Constructing Self-image }\end{array}$ \\
\hline $\begin{array}{c}\text { Leary \&Kowalski } \\
\text { Kakemaer (1990) [14] }\end{array}$ & $\begin{array}{c}\text { Control the image of others } \\
\text { towards oneself }\end{array}$ \\
\hline Leary (1996) & $\begin{array}{c}\text { The degree of willingness to } \\
\text { manipulate and control one's } \\
\text { impression in the eyes of others }\end{array}$ \\
& $\begin{array}{c}\text { To exert interpersonal } \\
\text { relationships, build personal } \\
\text { identity and maintain self- } \\
\text { esteem, control others and then }\end{array}$ \\
\hline
\end{tabular}




\begin{tabular}{|c|c|}
\hline & $\begin{array}{c}\text { conform to their own } \\
\text { expectations }\end{array}$ \\
\hline $\begin{array}{c}\text { Park\&Kim } \\
(2009)\end{array}$ & $\begin{array}{c}\text { Get psychological comfort and } \\
\text { build relationships }\end{array}$ \\
\hline
\end{tabular}

\subsubsection{Self-presentation motivation}

Self-presentation refers to an individual user who shows the expected image of other users through actions or words. WeChat provides a platform for the self-display motivation of individual impression management, and the research finds that the images displayed by users in WeChat or WeChat friends circle are more inclined to positive information [15]. Therefore, social networking platforms provide the possibility for individual users to present positive images and control negative images (Bergman, Fear Rington, Davenport, \& Bergman) [16]. Some users find it difficult to show themselves in real life. For example, users with neurotic personality are more willing to show themselves safely on social network platforms [17]. Compared with face-to-face interaction, the asynchrony of interaction in social networks enables users to control how to display themselves and interact with others more effectively, and provides conditions for users to display themselves on social networks [18]. Selfpresentation is to promote social interaction, meet the expectations of society or interactive scenes, make interpersonal interaction go smoothly, and thus obtain material or social rewards beneficial to oneself [19].

Furthermore, the following hypothesis $\mathrm{H} 1$ is put forward: users' self-presentation on WeChat is positively correlated with impression management motivation.

\subsubsection{Motivation to maintain self-esteem}

Leary(1996) think that users' motivation for impression management is to enhance interpersonal interaction and build personal identity to maintain self-esteem. Social psychology research has found that self-esteem is an important factor affecting users' impression management behavior. Smith and Mackie believe that "self-esteem is a kind of self-feeling, a positive or negative evaluation of an individual's self", and individuals with high self-esteem are more willing to act according to their beliefs. They will stand up for their beliefs and goals, be willing to contact others and take risks [20]. Schlenker believes that the level of self-esteem score is related to the influence of management behavior. Users with high self-esteem scores have stronger opportunities to manage and protect their self-image. Schutz pointed out through research that people with high self-esteem are eager to form positive impressions that satisfy other users, while people with low self-esteem are more concerned about how not to create negative negative impressions on other users [21]. Niu Jing and Liu cuihong have confirmed in the study of self- esteem and impression management motivation that selfesteem has a positive predictive effect on impression management motivation. people with high self-esteem are more likely to conduct impression management in WeChat circle of friends, and the stronger the motivation for impression management is [22]. Because people with high self-esteem represent respect and attention to themselves, individuals with higher self-esteem want to show themselves from me through impression management, thus obtaining more recognition and respect [23].

Furthermore, the following assumptions are put forward: H2a: Users with high self-esteem show stronger impression management motivation on WeChat;

$\mathrm{H} 2 \mathrm{~b}$ : Users with low self-esteem show weak impression management motivation on WeChat.

\section{RESEARCH DESIGN}

\subsection{Research problem}

Research Issues According to the literature review of the above related issues, the author raises specific research questions: What is the motivation for users to use WeChat for impression management?

\subsection{Research method}

This study adopts the offline questionnaire survey method. In the aspect of questionnaire design, the motivation for WeChat use is designed in the form of Richter's five-level scale, with five measures from "very different meaning" to "very agree". This questionnaire survey is divided into two periods: from December 5, 2019 to January 31, 2020, it is distributed through online (quiz star) and 524 valid questionnaires are collected. Finally, SPSS is used for data statistical analysis.

\section{DATA ANALYSIS}

\subsection{Sample overall description}

A total of 524 valid questionnaires were collected in this survey, of which 272 were men, accounting for $51.91 \%$ of the sample. 525 women, accounting for $48.09 \%$ of the sample. On the time of using WeChat every day, 298 people use WeChat for more than three hours a day, accounting for $56.87 \%$ of the sample, while $24.05 \%$ and $19.08 \%$ use WeChat for one to two hours and one hour a day respectively. In terms of age distribution, 295 (56.3\%) were aged 19-26. 


\subsubsection{Statistical analysis of the self-expression scale (see Table 2)}

Table 2 Self-represented relationship description

\begin{tabular}{|c|c|c|}
\hline Item & $\begin{array}{c}\text { Mean } \\
\text { value }\end{array}$ & $\begin{array}{c}\text { Standard } \\
\text { deviation }\end{array}$ \\
\hline $\begin{array}{c}\text { I will share my life } \\
\text { on WeChat }\end{array}$ & 3.48 & 1.093 \\
\hline $\begin{array}{c}\text { When interesting } \\
\text { stories happen } \\
\text { around me, I will } \\
\text { quickly share them } \\
\text { on WeChat }\end{array}$ & 3.09 & 1.112 \\
\hline $\begin{array}{c}\text { I will change } \\
\text { WeChat avatar } \\
\text { regularly }\end{array}$ & 3.02 & 0.997 \\
\hline $\begin{array}{c}\text { I will post selfies in } \\
\text { WeChat friends } \\
\text { circle to show } \\
\text { myself }\end{array}$ & 3.00 & 1.260 \\
\hline $\begin{array}{c}\text { I often praise or } \\
\text { comment on other } \\
\text { people's published } \\
\text { content to express } \\
\text { my views }\end{array}$ & 4.06 & 1.032 \\
\hline
\end{tabular}

The mean value of these five items is 3.33 , which indicates that the surveyed objects have a relatively agreed attitude towards the above items. Among them, the average value of "I often praise or comment on other people's published content to express my views" is 4.06 , with the highest score among the five items.

\subsubsection{Statistical analysis of maintaining self- esteem scale (see Table 3)}

Table 3 Self-esteem relationship description

\begin{tabular}{|c|c|c|}
\hline Item & $\begin{array}{c}\text { Mean } \\
\text { value }\end{array}$ & $\begin{array}{c}\text { Standard } \\
\text { deviation }\end{array}$ \\
\hline $\begin{array}{c}\text { When speaking, I } \\
\text { will consider the } \\
\text { language and } \\
\text { content to avoid } \\
\text { making jokes }\end{array}$ & 3.80 & 0.967 \\
\hline I will make people & 3.68 & 1.121 \\
\hline
\end{tabular}

\begin{tabular}{|c|l|l|}
\hline $\begin{array}{c}\text { recognize and } \\
\text { respect me by } \\
\text { publishing some } \\
\text { information }\end{array}$ & ( & \\
\hline $\begin{array}{c}\text { I will release some } \\
\text { information to make } \\
\text { people think that I } \\
\text { am a serious } \\
\text { worker/learner }\end{array}$ & 3.41 & 1.138 \\
\hline $\begin{array}{c}\text { I think the } \\
\text { information I have } \\
\text { already published is } \\
\text { equivalent to my } \\
\text { taste }\end{array}$ & 3.49 & 0.935 \\
\hline
\end{tabular}

The average value of these five items is 3.595, which shows that maintaining self-esteem is a very important motivation for users to manage non-impression on WeChat Among them, the average value of "I will consider language and content and avoid making jokes" is 3.80, with the highest score among the five items.

\section{CONCLUSION}

Based on the integrated analysis of the questionnaire data, we will now answer the assumptions mentioned above.

H1: User's self-presentation on WeChat is positively related to impression management motivation.

When users use WeChat for online communication, they will publish real-life events to WeChat friends to express their views, and they will also praise the content published by WeChat friends to express their views and positions. Although the scores of posting selfies and regularly changing avatars on WeChat are not very high, there are also positive effects. Therefore, self-display on WeChat is positively related to impression management motivation. H2a: Users with high self-esteem show stronger impression management motivation on WeChat;

$\mathrm{H} 2 \mathrm{~b}$ : Users with low self-esteem have weak motivation to manage the negative line on WeChat.

High self-esteem represents respect and attention to oneself, so users will consider their own language and content when publishing some comments on WeChat, and at the same time, they will also release some information to make other users have expected respect for themselves, thus proving that people with high self-esteem will show stronger impression management motivation on WeChat social networking platform to obtain higher recognition and respect, on the contrary, people with low self-esteem will show relatively weak impression management motivation. 
[13] Baumeister, R. F. (1982). A self-presentational

\section{REFERENCES}

[1] Ke Li. Analysis of the image presentation of college students in SNS social networking sites based on impression management theory [D]. Wuhan: Huazhong University of Science and Technology, 2013.

[2] Goffman Erving (1959). The presentation of self in everyday life.New York: Doubleday.

[3] Schlenker, B.R(1980).Impression management: The self concept, social identity and interpresonal relations. Monterey, CA: Brooks.

[4] Arkin. (1981). Self-presentation style[A] In: Tedeschi J T (Eds.) Impression Management and Social Psychological Research. New York: Academic Press:311-333.

[5] Leary (1990). Social Anxiety and Self-Presentation: Conceptualization and Model, Psychological Bulletin, 92(3), 641-669.

[6] Schlenker, B.R(2004).Impression management: Course outline-Fall, SOP 6509-Seminar:Impression Management.

[6] Yao Qi, Ma Huawei, Yan Huan, et al. Analysis of individual behavior of social network users from the perspective of psychology [J]. Advances in Psychological Science, 2014, 22 (10): 1647-1659.

[7] Boyd, D.M, \& Eilison, N.B. (2007). Social network sites: Definition, history, and scholarship. Journal of Computer-Mediated Communication, 13, 210-230.

[8] He Ling. Self-presentation of the Internet community $[\mathrm{J}]$. Fudan Foreign Languages and Literatures Series, 2011 (1): 16.

[9] Li Weihua. Self-presentation in QQ space [D]. Lanzhou: Lanzhou University, 2009.

[10] Xun Xinyun. Self-presentation in blog communication [J]. Media Watch, 2013, 6: 008.

[11] Leary, M. R., \& Kowalski, R. M. (1990). Impression Management: A Literature Review and Two-Component Model. Psychological Bulletin, 107 (1): 34-47.

[12] Braslow, M. D., Guerrettaz, J., Arkin, R. M., \& Oleson, K. C. (2012). Self-doubt. Social and Personality Psychology Compass, 6 (6): 470-482. view of social phenomena. Psychological bulletin, 91(1), 3 .

[14] Leary, M. R., \& Kowalski, R. M. (1990). Impression management: A literature review and twocomponent model. Psychological bulletin, 107(1), 34.

[15] Jiang Yuanlun, Song Shaokang. Research on the Self-Disclosure of College Students on Social Media-A Comparative Analysis of Renren.com and WeChat [J]. Communication and Copyright, 2015 (6).

[16] Bergman, S. M., Fearrington, M. E., Davenport, S. W., \& Bergman, J. Z. (2011). Millennials, narcissism, and social networking: What narcissists do on social networking sites and why Personality and Individual Differences, 50, 706-711.

[17] Seidman, G. (2013). Self-presentation and belonging on Facebook: How personality influences social media use and motivations. Personality and Individual Differences, 54, 402-407.

[18] Toma, C. L., Hancock, J. T., \& Ellison, N. B. (2008). Separating fact from fiction: An examination of deceptive self-presentation in online dating profiles. Personality and Social Psychology Bulletin, 34, 10231036.

[19] Tedeschi J T, Schlenker B R, Bonoma T V. Cognitive Dissonance: Private Ratiocination or Public Spectacle[J]. American Psychologist, 1971, 26(8): 685.

[20] Baumeister, R. F. \&Tierney, J.(2011). Willpower: Rediscovering the greatest human strength. New York: The Penguin Press.

[21] Liu Juanjuan. Study on Impression Management of College Students and Its Influencing Factors [D]. Central China Normal University, 2005.

[22] Niu Jing, Liu Cuihong. An empirical study of impression management and public self-esteem and self-monitoring in social media use [D]. Huazhong University of Science and Technology, 2019.

[23] Johnson, \& Maarit. (2016). Relations between explicit and implicit self-esteem measures and selfpresentation. Personality and Indi- vidual Differences, 95, 159-161. 